\title{
Federal government unveils modest transparency initiative
}

$\mathrm{C}$ anada has dipped a toe into the waters of transparency that are sweeping through other nations by unveiling a tentative three-part plan to modestly improve citizen access to data.

But most health data will not be among those made more available as Health Canada and the Public Health Agency of Canada (PHAC) are not among the 10 departments and agencies that will be posting data at a new web portal. Moreover, licensing restrictions and vague requirements around what data are to be shared combine to make the initiative substantially narrower than those now underway in other nations like the United States.

The initiative will see the federal government share the data it collects in a "more useful format," proactively release information about its activities on an ongoing basis, and give Canadians "a stronger say" in policies and priorities through expanding "Web 2.0 technologies," the government claimed in unveiling its plans (http://open.gc .ca/open-ouvert/aop-apgo-eng.asp).

To that end, officials also launched an Open Government website with links to pre-existing disclosure pages on various department sites (http://open.gc.ca), and kicked off an open data pilot project to provide the public with "single-window access" to select federal datasets (www.data.gc.ca/default.asp?lang=En $\& n=F 9 B 7 A 1 E 3-1)$.

The initiative may constitute compliance with the government's long-overdue commitment to the Organisation for Economic Co-operation and Development to "launch a new portal to provide one-stop access to federal datasets" by the fall of 2010 (www.oecd.org/data oecd/48/56/46342001.pdf).

No rationale was provided for excluding Health Canada and PHAC from the pilot project. Only select datasets from 10 federal departments will be made available via the new portal, only one of which - Citizenship and Immigration Canada - was among the top five recipients of Access to

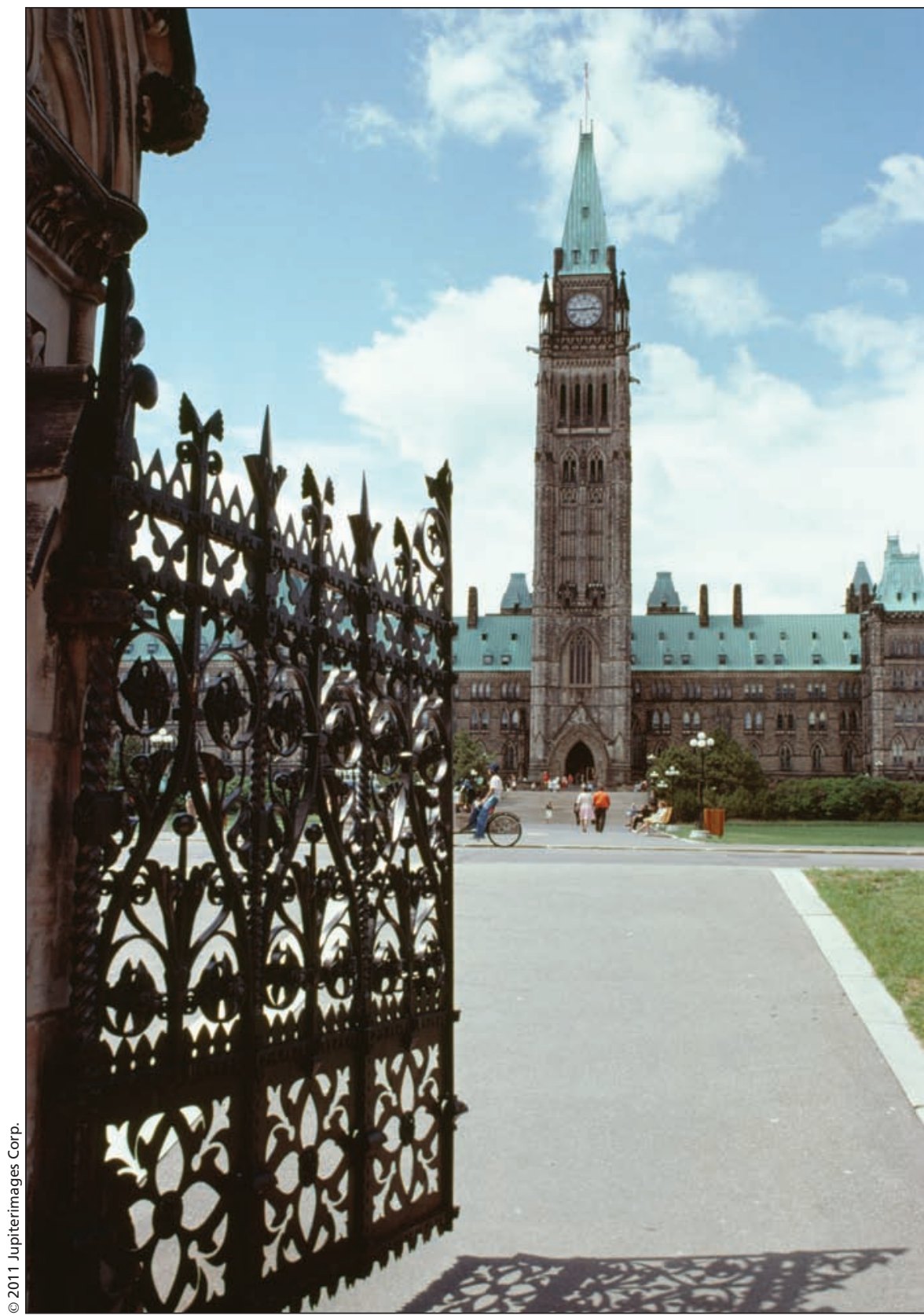

Long accused of systemic secrecy and reluctance to disclose information on issues ranging from food safety to drug approval, the federal government began to crack open the data gate by unveiling very modest transparency initiatives, primarily for datasets like ones on the number of dairy cows in Canada and soldiers of World War I. Datasets from Health Canada and the Public Health Agency of Canada were not included.

Information requests between 2009 and 2010 (www.infosource.gc.ca/bulletin /2010/b/bulletin33b/bulletin33b02-eng .asp). Health Canada received the fourth most requests during that period.
Those select datasets include:

- "Agriculture and Agri-Food Canada (Historical Milk Production by Calendar Year; and Number of Dairy Cows by Province) 
- Citizenship and Immigration Canada (Applications Processed Abroad and Processing Times; and Permanent Resident Summary by Mission)

- Environment Canada (Climate Data, in the context of the range of weather data available to the public; and Greenhouse Gas Emissions Reporting, Emissions Data)

- Department of Finance Canada (Financial data on government assets, liabilities, investments, expenditures, savings, transactions and conditions in fiscal reference tables)

- Fisheries and Oceans Canada (Canadian Tides and Water Levels Data Archive; and Maps and data via MAPSTER)

- Library and Archives Canada (Soldiers of the First World War CEF; and Maps, Plans and Charts of Canada)

- Natural Resources Canada (CanTopo, Canada, new generation of topographic maps; and $\mathrm{CanVec}$, Canada, digital cartographic reference product)

- Statistics Canada (Consumer Price Index, by province, monthly; and Gross domestic product at basic prices, by industry, monthly)

- Transport Canada (Civil Aircraft Register Database)

- Treasury Board of Canada Secretariat (Access to Information and Privacy Statistics)."

Health Canada has long faced criticism for the systemic secrecy in which it shrouds data, says Bill Jeffery, national coordinator of the Centre for Science in the Public Interest. "I've frequently heard it quipped that the department is more secretive than CSIS."

The department has also recently come under fire from health experts and open government policy wonks for keeping the data that inform its decision-making processes under wraps, ostensibly to protect industry interests (www.cmaj.ca/cgi/doi/10.1503/cmaj.109 -3837).

South of the border, industry resistance to greater transparency around health information, while "understandable," was not insurmountable to the release of thousands of community health datasets, says Dr. Patrick Conway, former chief medical officer in the policy division at the Office of the Secretary at the Department of Health and Human Services. The US is among a number of nations, including Great Britain, Australia, India and Brazil, which have aggressively proceeded with open government and open access policies.

In unveiling their plans, Canadian officials said that "all departments and agencies subject to the Access to Information Act will be expected to move toward proactively posting summaries of completed access to information requests." But Treasury Board President Stockwell Day fell short of either setting clear timelines for that change, or establishing requirements for any fur- ther disclosures to be made by participating departments (http://open.gc.ca /media/0318-eng.asp).

Such summaries are "cold comfort" in light of the fact that they are provided for information requests that get denied, and greater transparency in summary format falls well short of posting the data itself, says Jeffery. "It's not a panacea and it shouldn't relieve the government from acting in the public interest."

In comparison, the launch of the US Open Government Initiative was accompanied by detailed and specific requirements and deadlines for all federal departments and agencies to meet with regards to posting government information online, and included a requirement that the data be made available in open formats (www.white house.gov/sites/default/files/omb/assets /memoranda_2010/m10-06.pdf).

While most of the information currently posted on Canada's new open data portal is machine-readable, some maps and older data are posted as PDF documents or images. Users must also agree to a license in order to access the portal. That license contains restrictions on an individual or organization's ability to "disassemble, decompile ... [or] reverse engineer the data made available." No such clauses are found in open government licenses required by other nations. - Lauren Vogel, CMAJ

CMAJ 2011. DOI:10.1503/cmaj.109-3844 